\title{
In vitro toxic evaluation of two gliptins and their main impurities of synthesis
}

\author{
Camila F. A. Giordani', Sarah Campanharo ${ }^{1}$, Nathalie R. Wingert', Lívia M. Bueno', Joanna W. Manoel', \\ Barbara Costa ${ }^{2}$, Shanda Cattani ${ }^{2}$, Marcelo Dutra Arbo², Solange Cristina Garcia², Cássia Virginia Garcia', \\ Nádia Maria Volpato ${ }^{1}$, Elfrides Eva Scherman Schapoval ${ }^{1}$ and Martin Steppe ${ }^{1 *}$
}

From 2nd Latin American Congress of Clinical and Laboratorial Toxicology

Porto Alegre, Brazil. 3-6 June 2018

\begin{abstract}
Background: The presence of impurities in some drugs may compromise the safety and efficacy of the patient's treatment. Therefore, establishing of the biological safety of the impurities is essential. Diabetic patients are predisposed to tissue damage due to an increased oxidative stress process; and drug impurities may contribute to these toxic effects. In this context, the aim of this work was to study the toxicity, in 3 T3 cells, of the antidiabetic agents sitagliptin, vildagliptin, and their two main impurities of synthesis (S1 and S2; V1 and V2, respectively).

Methods: MTT reduction and neutral red uptake assays were performed in cytotoxicity tests. In addition, DNA damage (measured by comet assay), intracellular free radicals (by DCF), NO production, and mitochondrial membrane potential $(\Delta \psi M)$ were evaluated.

Results: Cytotoxicity was observed for impurity V2. Free radicals generation was found at $1000 \mu \mathrm{M}$ of sitagliptin and $10 \mu \mathrm{M}$ of both vildagliptin impurities (V1 and V2). A decrease in NO production was observed for all vildagliptin concentrations. No alterations were observed in $\Delta \psi \mathrm{M}$ or DNA damage at the tested concentrations.

Conclusions: This study demonstrated that the presence of impurities might increase the cytotoxicity and oxidative stress of the pharmaceutical formulations at the concentrations studied.
\end{abstract}

Keywords: Sitagliptin, Vildagliptin, Drug impurities, Cytotoxicity, Oxidative stress

\section{Background}

Drug toxicity is one of the main challenges for the pharmaceutical industry and it also contributes to latestage failures, increased cost, and market withdrawals [1]. Nowadays, besides the toxicity of compounds present in drug formulations, attention is being paid to the presence of impurities [2-6].

Impurities in pharmaceutical products involve undesirable chemicals that remain in active ingredients or are developed during formulation and also through aging as

\footnotetext{
* Correspondence: martin.steppe@ufrgs.br

'Laboratório de Controle de Qualidade Farmacêutico, Universidade Federal do Rio Grande do Sul (UFRGS), Porto Alegre, Brazil

Full list of author information is available at the end of the article
}

degradation products $[7,8]$. The presence of impurities is a significant problem in the synthesis of new compounds, since this process occurs in starting materials, solvents, intermediates and by-products [9].

Pharmacological and toxicological profiles are responsible for the safety of a drug, and adverse effects can be caused by the presence of impurities present in pharmaceutical products. Therefore, it is necessary to monitor and control impurities to ensure the quality and safety of pharmaceutical products [10].

Regulatory units are attentive to this issue and have been searching for different strategies to ensure the quality and safety of pharmaceutical preparations [11, 12]. According to ICH-Q3A (R2), there are reporting,

(c) The Author(s). 2019 Open Access This article is distributed under the terms of the Creative Commons Attribution 4.0 International License (http://creativecommons.org/licenses/by/4.0/), which permits unrestricted use, distribution, and reproduction in any medium, provided you give appropriate credit to the original author(s) and the source, provide a link to the Creative Commons license, and indicate if changes were made. The Creative Commons Public Domain Dedication waiver (http://creativecommons.org/publicdomain/zero/1.0/) applies to the data made available in this article, unless otherwise stated. 
identification, and qualification thresholds. The latter relates to the data acquisition and evaluation process that determines the biological safety of an impurity or a profile of impurities at a safe level [13]. The thresholds for qualification of impurities are based on individual drugs, therefore evidence of the presence of such impurities is important when they are related with adverse reactions in patients [11].

Toxicity tests are used to evaluate the potential of a chemical in causing harmful effects in experimental systems. The research can be carried out on the drug product or substance containing impurities or on isolated impurities [13]. Among these deleterious effects, there is the possibility of impurities that induce genetic mutations, breaks, and/or chromosomal rearrangements, with the potential to promote neoplastic alterations $[14,15]$. Related to this, the European Medicines Agency (EMEA) published a guide in 2006 recommending that impurities should be identified concerning their genotoxicity or whether their chemical structure is an alert for toxicity. The concept of a toxicological concern threshold was also adopted, which establishes the safe dose for all potential carcinogens, corresponding to $15 \mu \mathrm{g}$ per day [1416]. The ICH M7 official guide determines the levels of impurities that are not carcinogenic and presents tests that evaluate the mutagenic control present in active substances or final products in order to ensure safety and quality for users [17].

Late complications of diabetes have been linked to hyperglycemia-induced oxidative stress. The mechanisms underlying hyperglycemia-mediated cellular damage include the formation of advanced glycation endproducts, increased oxidative stress, mitochondrial dysfunction, and activation of the polyol and hexosamine pathways [18]. There is evidence that the main source of oxidative species production in diabetes is mitochondria [19]. Abnormal mitochondrial functions and excessive production of free radicals play a primary role in the onset of diabetes and its complications. Liver and kidney damage, which was partially reverted with $\mathrm{n}$-acetylcysteine treatment, was observed in diabetic rats [20]. In humans, early kidney impairment was related to a hyperglycemiainduced oxidation process [21]. In this scenario, the presence of toxic impurities in therapeutic drugs may compromise treatment, aggravating disease complications.

At the moment, there are no studies reported in the literature regarding the toxicity of gliptin impurities. Therefore, the aim of this work was to study the toxicity of the drugs sitagliptin and vildagliptin and their main impurities of synthesis, using the mouse fibroblast $3 \mathrm{~T} 3$ cell line as an in vitro model, as well as some underlying mechanisms related to their toxicity. Cytotoxicity was evaluated through the MTT reduction and neutral red (NR) uptake assays. In addition, some mechanisms such as oxidative stress (oxidative species production), inflammation (nitric oxide), mitochondrial function, and genotoxicity were also evaluated.

\section{Material and methods \\ Chemicals}

Sitagliptin phosphate reference standard (99.5\%), vildagliptin reference standard (99.5\%), and 3-(trifluoromethyl)-5,6, 7,8-tetrahydro -[1, 2, 4] triazolo [4,3-a]pyrazine- $\mathrm{HCl}$ (99.3\%) (impurity S1) were supplied by Sequoia Research Products (Oxford, UK). O-benzylhydroxylamine hydrochloride (99.0\%) (impurity S2), 2-pyrrolidinecarboxamide (98.0\%) (impurity V1) and 3-amino-1-adamantanol (96.0\%) (impurity V2) were supplied by Sigma-Aldrich (Brazil).

All chemicals were used as supplied. Stock solutions of sitagliptin, vildagliptin, and impurities S1, S2, V1, and V2 were made in purified water obtained from Millipore ${ }^{\circ}$. All stock solutions were stored at $-20^{\circ} \mathrm{C}$ and freshly diluted on the day of the experiment.

\section{Cell culture}

The $3 \mathrm{~T} 3$ cell line was routinely cultured in $75 \mathrm{~cm}^{2}$ flasks (Kasvi, São José dos Pinhais, PR, Brazil) using DMEM supplemented with $10 \%$ heat inactivated fetal bovine serum (FBS), $100 \mathrm{U} \mathrm{mL}^{-1}$ penicillin (Gibco, Paisley, UK), and $100 \mathrm{mg} \mathrm{mL}^{-1}$ streptomycin (Gibco, Paisley, UK). The cells were maintained at $37^{\circ} \mathrm{C}$ in a humidified $5 \%$ $\mathrm{CO}_{2}-95 \%$ air atmosphere. The cells were fed every $2-3$ days, and sub-cultured once $70-80 \%$ confluence was reached.

\section{Cytotoxicity assays}

The cytotoxicity was evaluated through the MTT reduction and NR uptake assays. The cells were seeded at a density of 3000 cells per well in 96 well plates. Triton X100 1\% (Sigma-Aldrich, St. Louis, USA) was used as a positive control. Negative control cells were incubated in culture medium. Concentration-response curves were obtained by incubating the cells with $0.5,10,50,100$, 500 , and $1000.0 \mu \mathrm{M}$ of sitagliptin, vildagliptin and their respective impurities for $24 \mathrm{~h}$ at $37^{\circ} \mathrm{C}$.

\section{MTT reduction assay}

The MTT reduction assay was performed as previously described [22]. After 24 $\mathrm{h}$ of incubation of the cells with the drugs and impurities, the medium was removed and replaced by a fresh medium containing $0.5 \mathrm{mg} \mathrm{mL}^{-1}$ MTT (Sigma-Aldrich, St. Louis, USA). The cells were incubated at $37^{\circ} \mathrm{C}$ for $2 \mathrm{~h}$. Afterwards, the cell culture medium was removed and the formed formazan crystals were dissolved in DMSO. The absorbance was measured at $550 \mathrm{~nm}$ in a multi-well plate reader (SpectraMax M2e, SoftMax ${ }^{\oplus}$ Pro 5, Molecular Devices, Sunnyvale, CA, USA). The results were graphically presented as percentage of 
MTT reduction vs. concentration $(\mu \mathrm{M})$. All the drugs and impurities were tested in three independent experiments with each concentration tested in three replicates within each experiment.

\section{Neutral red uptake assay}

The assay was performed according to OECD document 129 [23] and as previously described by Arbo et al. (2014) [18]. At the end of the $24 \mathrm{~h}$ of incubation-time of the cells with drugs and impurities, the medium was replaced by new medium containing $50 \mu \mathrm{g} \mathrm{mL}^{-1} \mathrm{NR}$ (Sigma-Aldrich, St. Louis, USA) and incubated at $37^{\circ} \mathrm{C}$ for $3 \mathrm{~h}$. After that, the cells were lysed with a $50 \%$ ethanol: $1 \%$ glacial acid acetic solution (v/v) (Sigma-Aldrich, St. Louis, USA). The absorbance was measured at 540 $\mathrm{nm}$ in a multi-well plate reader (SpectraMax M2e, SoftMax ${ }^{\circ}$ Pro 5, Molecular Devices, Sunnyvale, CA, USA). The percentage of NR uptake relative to the control cells was used as the cytotoxicity measure. All the drugs were tested in three independent experiments with each concentration tested in three replicates within each experiment.

\section{Measurement of intracellular oxidative species}

The intracellular oxidative species production was monitored by means of the DCFH-DA assay, as previously described [22]. For this determination, the cells were seeded at a density of 3000 cells per well in 96 well plates and allowed to grow for $24 \mathrm{~h}$. On the day of the experiment, the cells were pre-incubated with $10 \mu \mathrm{M}$ of DCFH-DA for $30 \mathrm{~min}$ at $37^{\circ} \mathrm{C}$ in the dark. The cells were rinsed with PBS and incubated with the drugs and their impurities at 10,100 , and $1000 \mu \mathrm{M}$ for $24 \mathrm{~h} . \mathrm{H}_{2} \mathrm{O}_{2}$ $(150 \mathrm{mM})$ was used as a positive control. Fluorescence was recorded in a fluorescence microplate reader (SpectraMax M2e, SoftMax ${ }^{\circledR}$ Pro 5, Molecular Devices, Sunnyvale, CA, USA) set at $485 \mathrm{~nm}$ excitation and $530 \mathrm{~nm}$ emission. The data obtained were calculated as the percentage of control conditions for each experiment from at least three independent experiments with each concentration tested in three replicates within each experiment.

\section{Measurement of nitric oxide}

The cells were seeded at a density of 50,000 cells per well in 96 well plates and allowed to grow for $24 \mathrm{~h}$. The drugs and their impurities were incubated at 10, 100, and $1000 \mu \mathrm{M}$ for $24 \mathrm{~h}$ at $37^{\circ} \mathrm{C}$. After the incubation time, $100 \mu \mathrm{L}$ of supernatant was transferred to another plate, $100 \mu \mathrm{L}$ Griess reagent was added, and the plate was incubated at $37^{\circ} \mathrm{C}$. After $20 \mathrm{~min}$ of incubation time, the absorbance was measured at $540 \mathrm{~nm}$ in a multi-well plate reader (SpectraMax M2e, SoftMax Pro 5, Molecular Devices, Sunnyvale, CA, USA). The data obtained were calculated as the percentage of control conditions for each experiment from three independent experiments with each concentration tested in three replicates within each experiment.

Assessment of mitochondrial membrane potential $(\Delta \psi \mathrm{m})$ The estimation of $\Delta \psi \mathrm{m}$ contributes with important information about the mitochondrial function and also about the physiological state of the cell [24]. The evaluation of mitochondrial integrity was performed by measuring tetramethylrhodamine ethyl ester (TMRE) (Sigma-Aldrich, St. Louis, USA) inclusion as previously described [22]. The cells were seeded at a density of 3000 cells per well. After $24 \mathrm{~h}$ of incubation at $37^{\circ} \mathrm{C}$, the medium was gently aspirated and the cells were incubated with the drugs and their impurities at 10,100 , and $1000 \mu \mathrm{M}$ for $24 \mathrm{~h}$. Then, the medium was substituted by a new medium containing $2 \mu \mathrm{M}$ of TMRE for $30 \mathrm{~min}$ at $37^{\circ} \mathrm{C}$ in the dark. Afterwards, the medium was gently aspirated and replaced by phosphate buffer. Fluorescence was measured in a fluorescence microplate reader set to $544 \mathrm{~nm}$ excitation and 590 $\mathrm{nm}$ emission. The data obtained were calculated as the percentage of control conditions for each experiment from three independent experiments with each concentration tested in three replicates within each experiment.

\section{Comet assay}

The cells were seeded in 12-well plates (Nest Biotech Co., Ltd., China) at a density of 200,000 cells per well. After $24 \mathrm{~h}$, the medium was aspirated and the cells were incubated with the drugs and their impurities at 10, 100, and $1000 \mu \mathrm{M}$ at $37^{\circ} \mathrm{C}$. After $24 \mathrm{~h}$ of incubation time, the cells were harvested by trypsinization (0.05\% trypsin/ EDTA). The cell suspensions were centrifuged $(400 \times \mathrm{g}, 5$ min, $4{ }^{\circ} \mathrm{C}$ ), the obtained cell pellets were resuspended in low-melting point agarose $(0.75 \%, 150 \mu \mathrm{L})$ (Sigma-Aldrich (St. Louis, USA) and $60 \mu \mathrm{L}$ aliquots were distributed on two slides coated with $1 \%$ normal-melting agarose. The samples were incubated in lysis solution (2.5 M NaCl, $100 \mathrm{mM}$ EDTA, 10 mMTris- $\mathrm{HCl}$, distilled water, $10 \%$ DMSO, and $1 \%$ Triton $\mathrm{X}-100$ ) at $4{ }^{\circ} \mathrm{C}$ for 24 $\mathrm{h}$ in the dark. The slides were then incubated with alkaline electrophoresis running buffer $(300 \mathrm{mM} \mathrm{NaOH}$ and $1 \mathrm{mM}$ EDTA, $\mathrm{pH}$ 13) for $20 \mathrm{~min}$ at $4{ }^{\circ} \mathrm{C}$ before electrophoresis, which was carried out for $20 \mathrm{~min}$ at $25 \mathrm{~V}$ and $300 \mathrm{~mA}$. After that, the slides were neutralized with 0.4 M Tris-HCL for $15 \mathrm{~min}$ in the dark. The DNA was fixed by immersing the slides in $70 \%$ ethanol for $15 \mathrm{~min}$ and in absolute ethanol for a further $15 \mathrm{~min}$ and left to dry overnight. For the microscopy analysis, the dried slides were stained with gel red $(20 \mu \mathrm{g} / \mathrm{mL})$ and DNA migration was observed in at least 100 cells at 400x magnification using a fluorescence microscope (Olympus, Japan) equipped with a 510-550 $\mathrm{nm}$ excitation filter of connected to a camera. The images were evaluated by Comet Score ${ }^{\text {Ta }}$ software, obtained from the public domain (http://www. 
tritekcorp.com/products_cometscore.php). The percentage of DNA in the comet tail (\% DNA in tail) was the parameter evaluated to describe comet formation [25]. Concurrently with the comet assay, an extra and identical replicate comet slide was prepared, lysed, and immediately fixed and stained without electrophoresis for evaluation of the cytotoxicity using the low molecular weight (LMW) DNA diffusion assay [26].

\section{Statistical analysis}

The results are presented as mean \pm standard error of the mean (SEM) from at least three independent experiments. Normality of the data distribution was assessed by the Kolmogorov-Smirnov normality test. Significance was accepted at $p<0.05$. Statistical comparisons between groups were performed by one-way ANOVA (when the data followed a normal distribution) or with the Kruskal-Wallis test (in the case of non-normal data distribution). Details of the statistical analysis are provided in the text and legend of the figures.

\section{Results and discussion}

Sitagliptin and vildagliptin are used for the treatment of diabetes mellitus. They are well tolerated, with a low risk of hypoglycemia, they do not cause weight gain, and they are administered once a day [27]. The safety of pharmaceutical products should be considered, especially in chronic use where the daily accumulation of an impurity may compromise the patient's health. The official guides recognize the importance of controlling drug impurities in order to limit human exposure; therefore, knowledge of the toxicity of impurities is necessary.

As far as we know, this is the first study to investigate the toxicity of sitagliptin and vildagliptin, and their main impurities of synthesis. This is important because diabetes mellitus is a chronic disease related to oxidative stress and tissue damage such as diabetic nephropathy, diabetic neuropathy, and diabetic retinopathy. The presence of toxic impurities in drug formulations might compromise, or even worse the disease. The cytotoxicity analysis was carried out by incubating the $3 \mathrm{~T} 3$ cells with $0-1000 \mu \mathrm{M}$ of sitagliptin, vildagliptin and their impurities for $24 \mathrm{~h}$. The results obtained in the MTT reduction assay are presented in Fig. 1a-f. It was possible to observe a significant $(p<0.001$, ANOVA/Bonferroni) decrease in MTT reduction at 500 and $1000 \mu \mathrm{M}$ of V2 (Fig. 1f). No alterations in cell viability were observed after incubation of the $3 \mathrm{~T} 3$ cells with sitagliptin (Fig. 1a), impurity S1 (Fig. 1b), impurity S2 (Fig. 1c), vildagliptin (Fig. 1d) and impurity V1 (Fig. 1e). The assay evaluates the reduction of MTT tetrazolium salt (soluble in water) to formazan MTT (water insoluble) by cellular dehydrogenases within the metabolically active cells. This occurs when mitochondrial enzymes are active; correlating the number of viable cells with the increase in formazan production is used as an index of cell
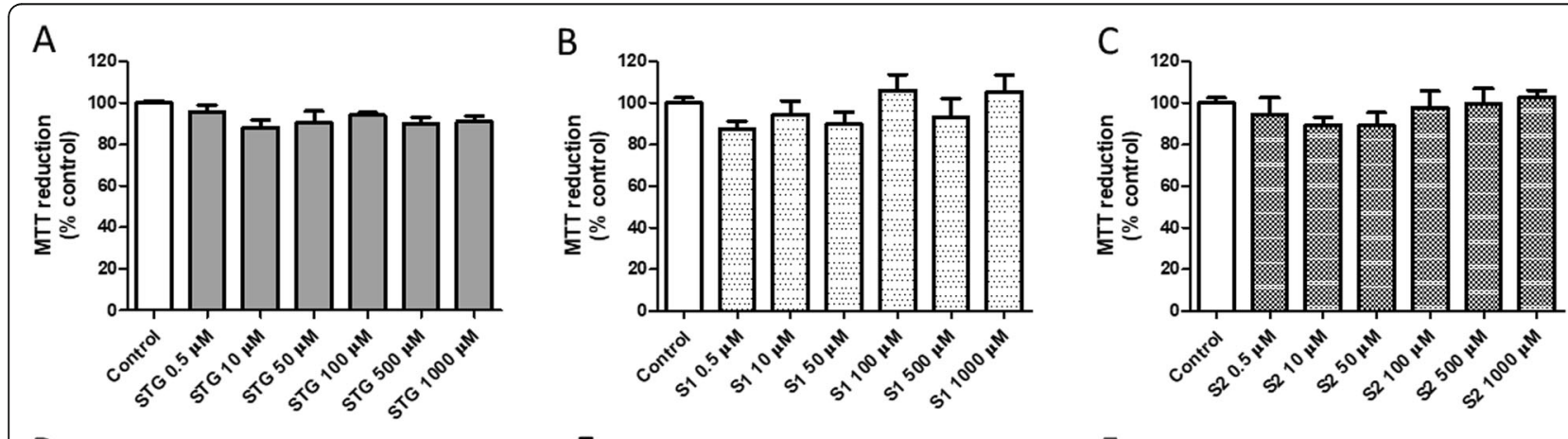

D

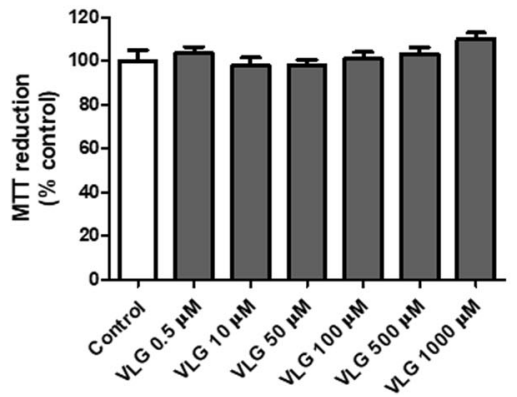

E

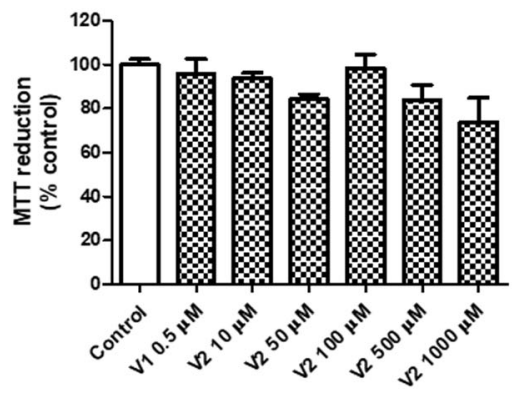

$\mathrm{F}$

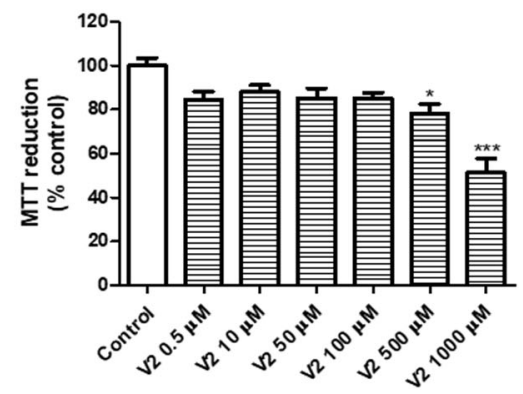

Fig. 1 Cell viability evaluated by the MTT reduction assays in 3 T3 cells after $24 \mathrm{~h}$ incubations with: a sitagliptin - STG, b impurity S1, c impurity $\mathrm{S} 2$, d vildagliptin - VLG, e impurity V1, f impurity V2. Results are expressed as mean \pm standard error of the mean. Statistical analysis performed through ANOVA/Bonferroni ( ${ }^{*} p<0.05 ;{ }^{* *} p<0.001$ versus control) 
viability [28]. However, mitochondrial succinate dehydrogenase is susceptible to local modifications in ion concentrations and ion flux and a couple of chemicals that increase metabolic activity in a cell would result in increased mitochondrial succinate dehydrogenase activity [22].

In the NR up-take assay (Fig. 2a-f), sitagliptin presented significant $(p<0.001$, ANOVA/Bonferroni) cytotoxicity at concentrations of 500 and $1000 \mu \mathrm{M}$ (Fig. 2a). In addition, impurity V2 also showed significant $(p<$ 0.01 , ANOVA/Bonferroni) decrease in cell viability at $1000 \mu \mathrm{M}$, the highest concentration (Fig. 2f), thus corroborating the results obtained with the MTT reduction assay. No alterations in cell viability were observed after incubation of the $3 \mathrm{~T} 3$ cells with impurity S1 (Fig. 2b), impurity S2 (Fig. 2c), vildagliptin (Fig. 2d) and impurity V1 (Fig. 2e). The neutral red uptake assay is based on the ability of the lysosomes of viable cells to incorporate the dye [29]. Interestingly, the results obtained by both tests generated slight variations, probably due to the use of different methods. This is not uncommon. Cadmium chloride $\left(\mathrm{CdCl}_{2}\right)$ cytotoxicity was evaluated in HepG2 cells by MTT reduction, neutral red uptake, protein quantification, and LDH activity assays, and MTT reduction was shown to be more sensitive [30]. In contrast, in our research, the neutral red uptake assay was more sensitive compared to the MTT one for sitagliptin. Among the impurities, impurity V2 of vildagliptin showed toxicity through both MTT and neutral red assays.

The effect of the drugs and their impurities on the generation of reactive species was evaluated by the DCFH-DA. This compound crosses cell membranes and it is enzymatically hydrolyzed by intracellular esterases in non-fluorescent dichlorodihydrofluorescein (DCFH). In the presence of oxidative species, this is oxidized to form a fluorescent compound (DCF) [31]. Figure 3a,b shows the results of the ROS and RNS production. A significant $(p<0.01$, ANOVA/Bonferroni) increase in oxidative species was observed at $1000 \mu \mathrm{M}$ of sitagliptin (Fig. 3a) and at $10 \mu \mathrm{M}$ of impurities V1 and V2 (Fig. 3b). At high concentrations, free radicals can cause damage to lipids, proteins, and DNA, compromising the function of enzymes or transporters [4, 24]. Our results indicated an increase in the oxidative species production at $1000 \mu \mathrm{M}$ of sitagliptin, suggesting that oxidative stress plays a role in its cytotoxicity. Increased reactive oxidative species were also observed for $10 \mu \mathrm{M}$ of impurities V1 and V2. Considering that no cytotoxicity was observed at the same concentration level, it is supposed that compensatory mechanisms could be activated to counteract the free radicals at higher concentration levels.

As depicted in Fig. 4a,b, the results obtained for NO production show that nor sitagliptin (Fig. 4a) or vildagliptin (Fig. 4b) impurities did not significantly alter the NO levels

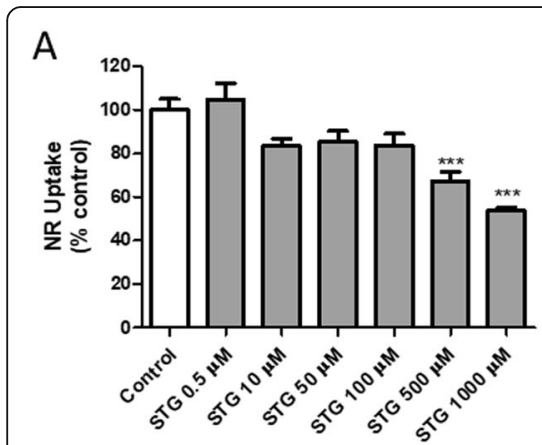

D

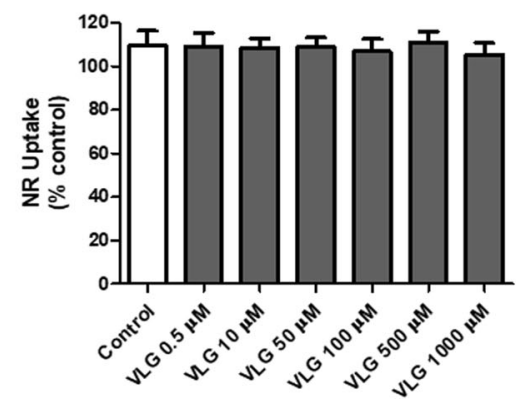

B

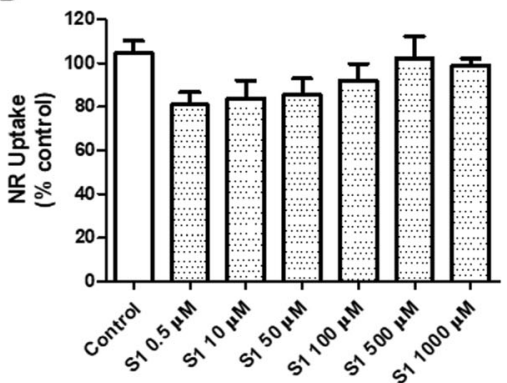

$E$

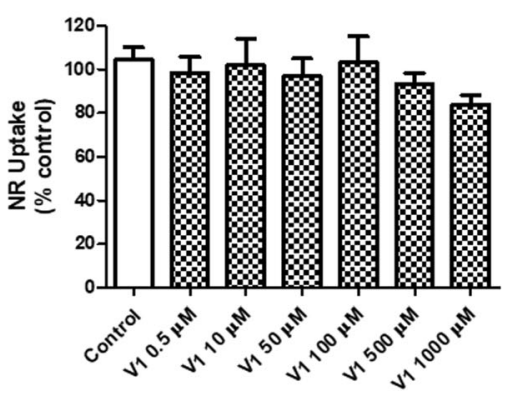

C

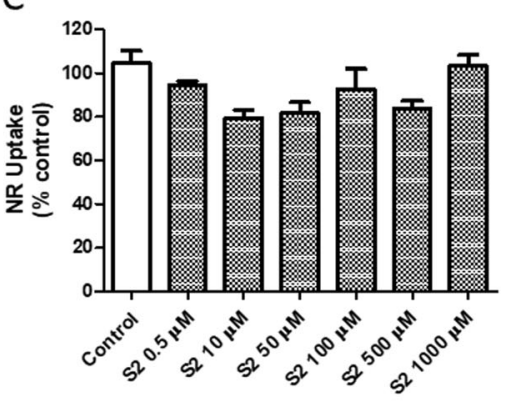

$\mathrm{F}$

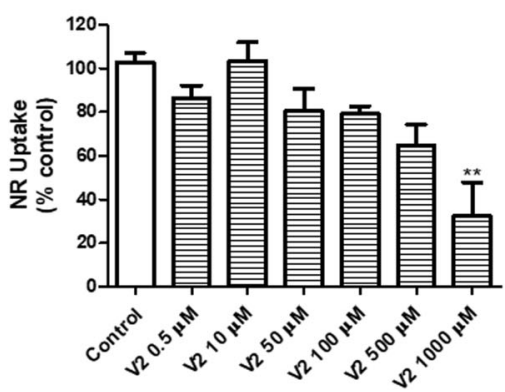

Fig. 2 Cell viability evaluated by the neutral red uptake in 3 T3 cells after $24 \mathrm{~h}$ incubations with: a sitagliptin - STG, b impurity S1, c impurity S2, d vildagliptin - VLG, e impurity V1, f impurity V2. Results are expressed as mean \pm standard error of the mean. Statistical analysis performed through ANOVA/Bonferroni $\left({ }^{* *} p<0.01 ;{ }^{* *} p<0.001\right.$ versus control) 


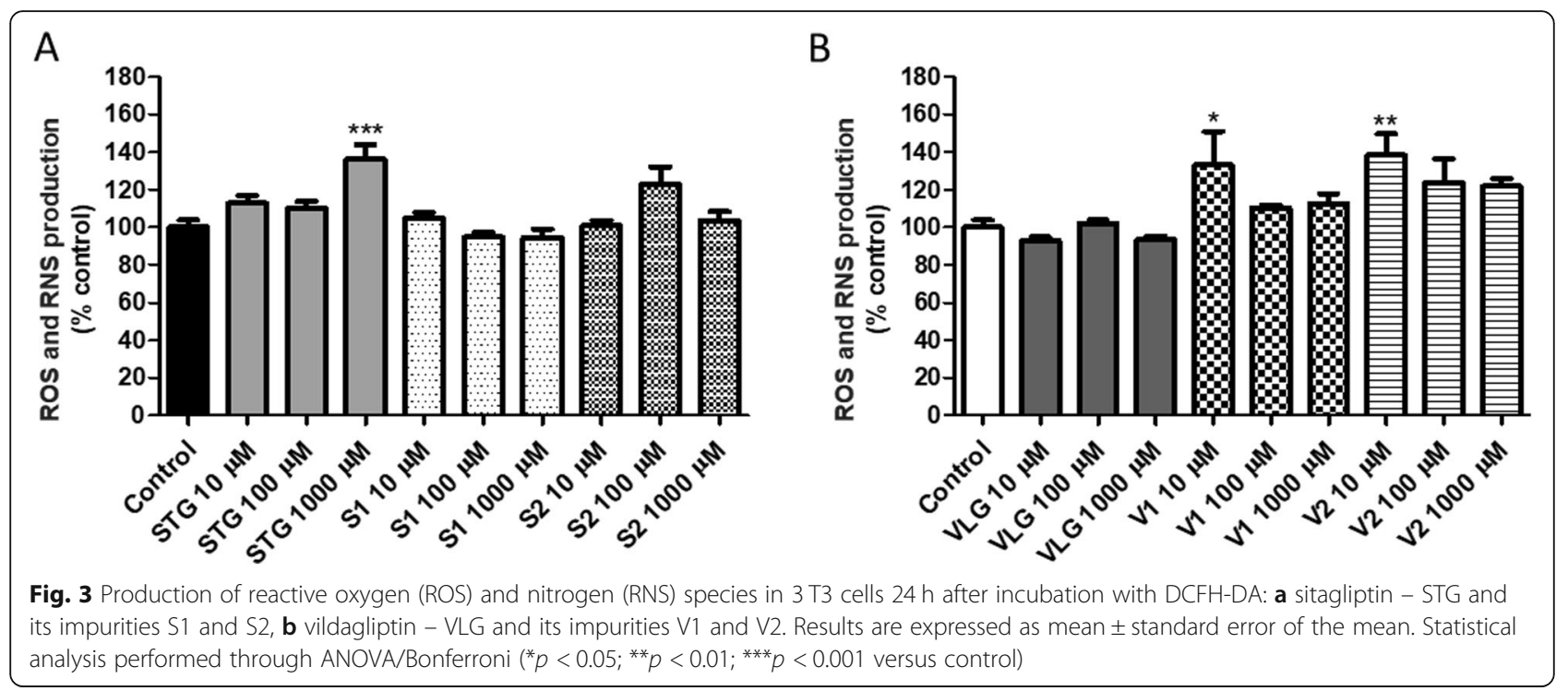

after $24 \mathrm{~h}$ of incubation. In cell culture conditions, NO formation from nitric oxide synthase accounts for the majority of nitrite, which is the major pathway for NO metabolism [32]. However, when there is an increase in reactive species, these free radicals may also mediate the endogenous formation of NO. This small molecule is related to chronic inflammatory diseases, playing an important role in the pathophysiology of different inflammation models [33]. The overproduction of NO from NO synthase and the activation of this enzyme by macrophages contribute to inflammation, cancer, diabetes and autoimmune disorders [34]. Interestingly, the antidiabetic drug vildagliptin presented a significant decrease in NO levels compared to the control (Fig. 4b).
This result point to other beneficial effects of the drug in diabetes besides decreased glycemia levels and, the presence of the impurities in drug formulations could be detrimental to this effect.

In order to investigate whether the compounds could disturb the mitochondrial function, the mitochondrial membrane potential was evaluated. In cells, mitochondria play an important role in normal function and are a regulator during the transition of cell death by both necrosis and apoptosis [35]. $\Delta \psi \mathrm{m}$ is responsible for controlling the accumulation of $\mathrm{Ca}^{2+}$ in the mitochondrial matrix, respiration and also the synthesis of ATP [36]. Because of its crucial role in the maintenance of the physiological function of the respiratory chain generating

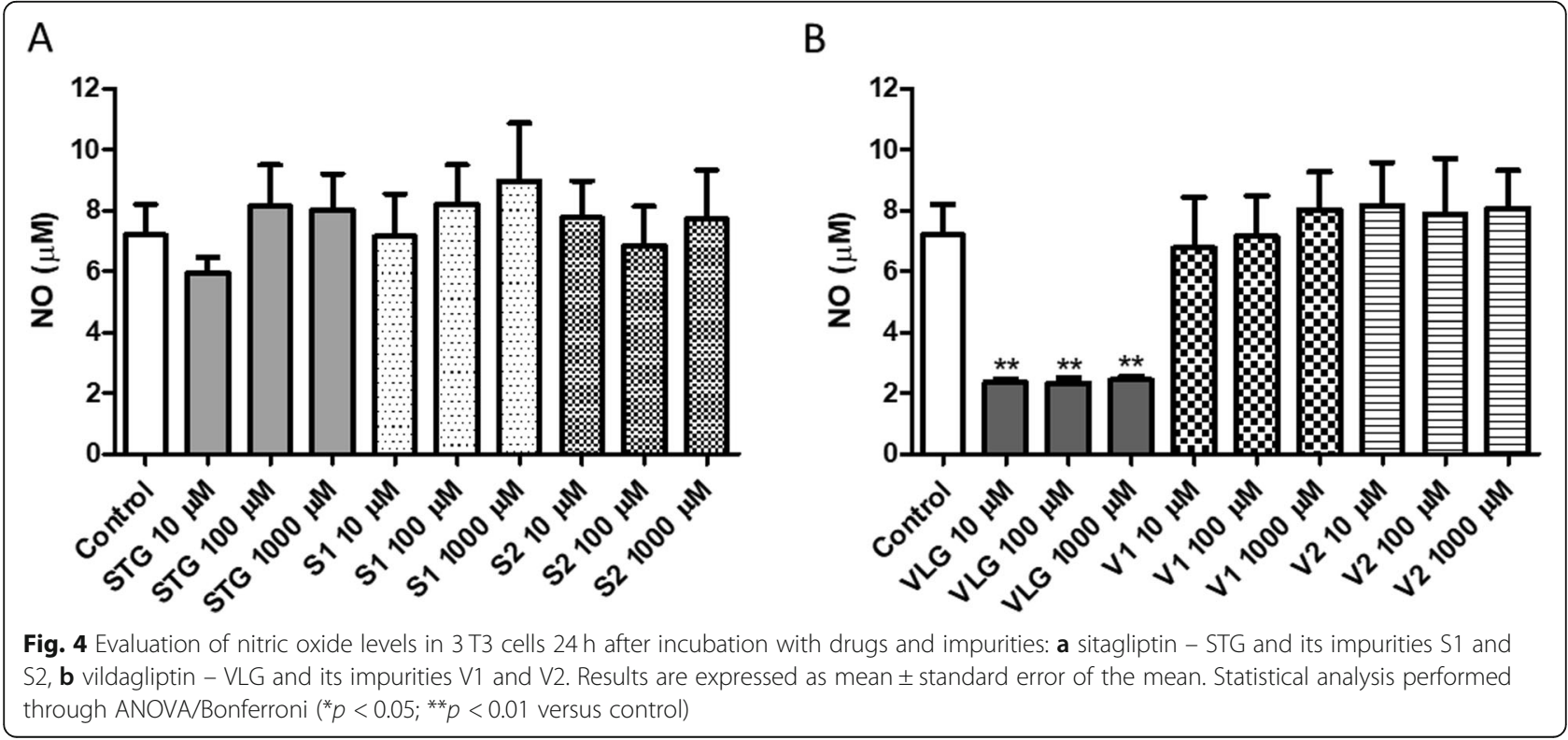




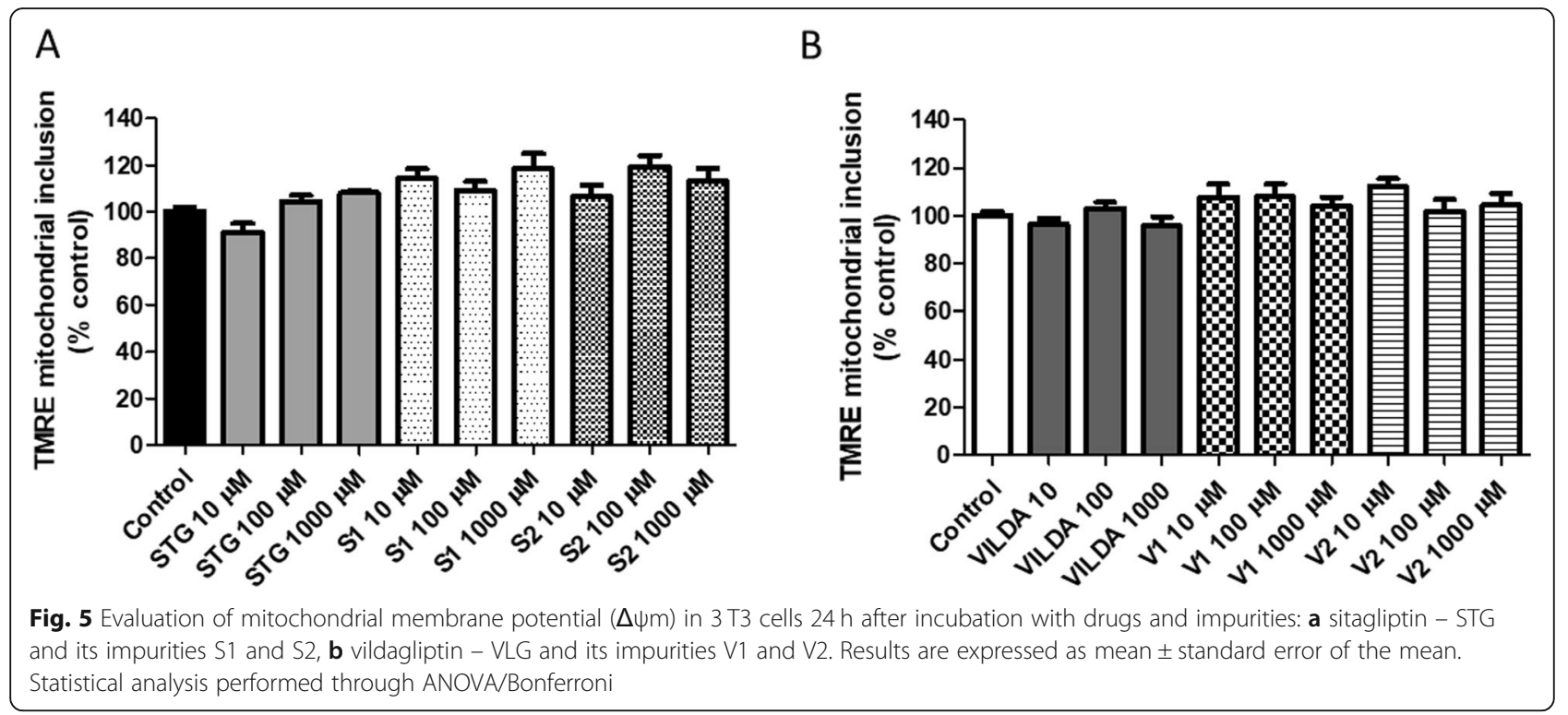

ATP, changes in $\Delta \psi \mathrm{m}$ compromise oxidative phosphorylation by reducing cell energy and inducing cell death [24]. As shown in Fig. 5a,b, no significant alterations were found in $\Delta \psi \mathrm{m}$ after $24 \mathrm{~h}$ of incubations of the $3 \mathrm{~T} 3$ cells with sitagliptin (Fig. 5a), vildagliptin (Fig. 5b), or their respective impurities.
The comet assay represents the capacity of negatively charged fragments of DNA to be extracted through an agarose gel in response to an electric field. It is a rapid, sensitive, and simple method for detecting DNA damage [37]. For this evaluation, the shape, size, and amount of DNA in comets are important for the test and correlate

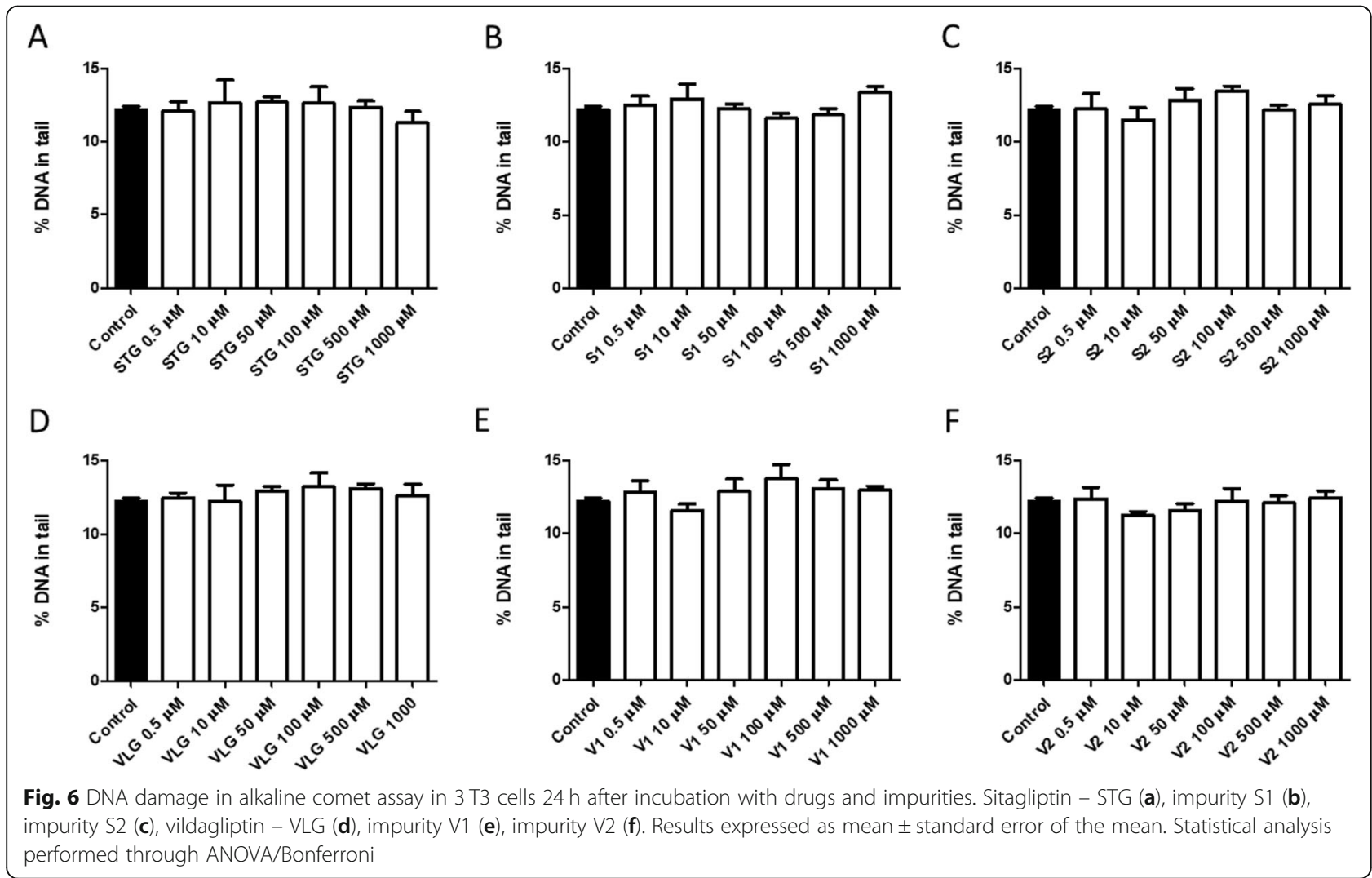




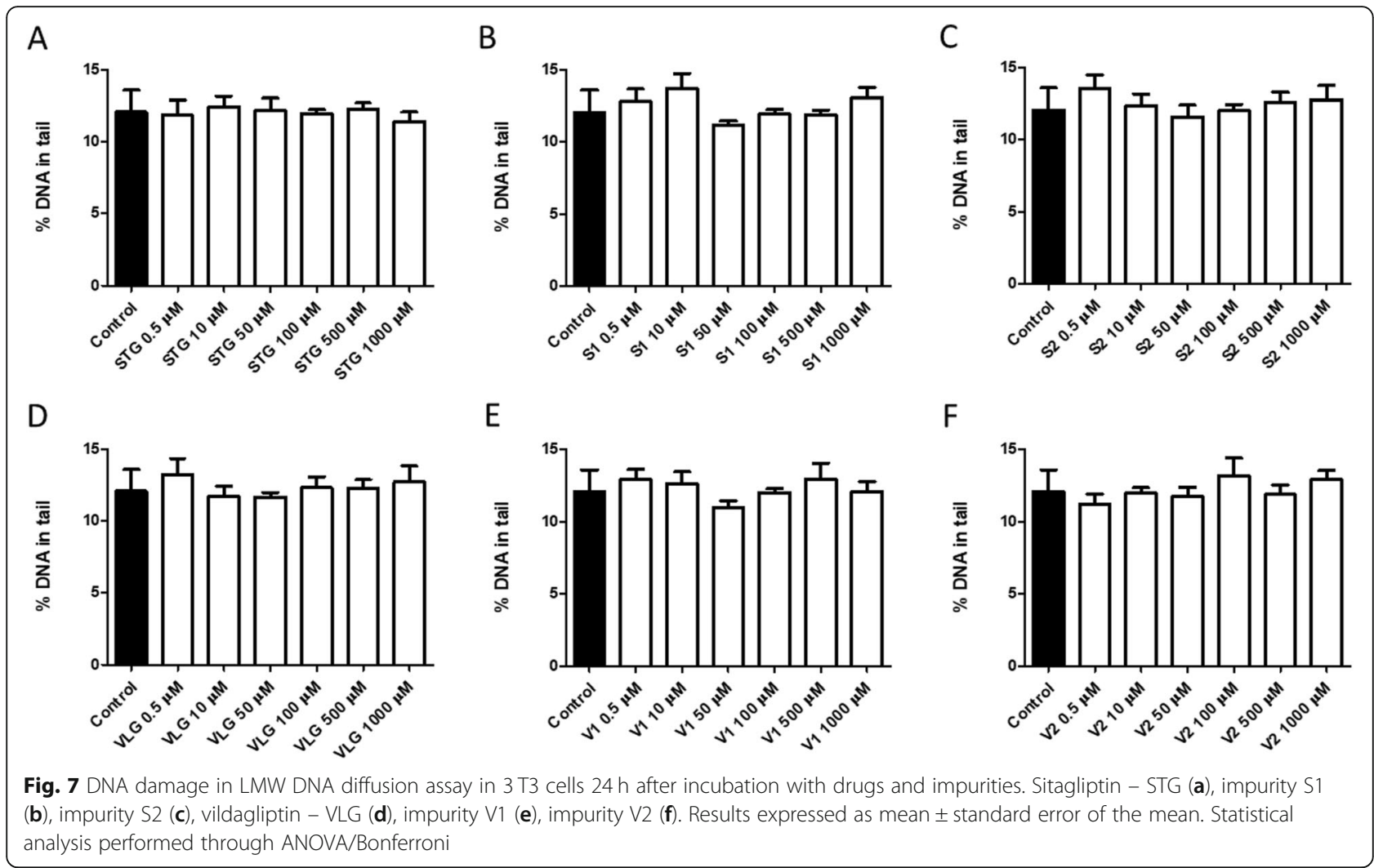

with the extent of DNA damage [37]. The results obtained by the alkaline comet assay indicate that neither sitagliptin (Fig. 6a), impurity S1 (Fig. 6b), and impurity S2 (Fig. 6c) nor vildagliptin (Fig. 6d), impurity V1 (Fig. 6e), and impurity V2 (Fig. 6f) elicited DNA breaks at the tested concentrations. The results of the LMW DNA diffusion assay indicated that, under our experimental conditions, neither sitagliptin (Fig. 7a), impurity S1 (Fig. 7b), and impurity S2 (Fig. 7c) nor vildagliptin (Fig. 7d), impurity V1 (Fig. 7e), and impurity V2 (Fig. 7f) induced significant cell death by apoptosis or necrosis.

\section{Conclusion}

The safety of pharmaceutical products is important, mainly in chronic use due to their daily accumulation. In this case, the presence of impurities may compromise the patient's health, and it is important to evaluate their toxicities. For the first time, the cytotoxicity of sitagliptin, vildagliptin and their chemical synthesis impurities were described in mouse fibroblast 3 T3 cells. Sitagliptin presented cytotoxicity at 500 and $1000 \mu \mathrm{M}$ and increased oxidative species at $1000 \mu \mathrm{M}$ but also decreased NO production at all concentrations. Moreover, except for impurity V2, the other impurities did not elicit significant cytotoxicity. This study provides important information to ensure the safety and quality of these drugs, which are available in the market. Furthermore, the presence of toxic impurities could be detrimental for diabetic patients, contributing to the tissue damage related to the progression of the disease and decreasing the therapeutic effect of the drugs.

\section{Acknowledgements}

Authors are thankful to CAPES and CNPq (Brazil) for financial support.

\section{About this supplement}

This article has been published as part of BMC Pharmacology and Toxicology Volume 20 Supplement 1, 2019: Proceedings of Toxi-Latin 2018. The full contents of the supplement are available online at https://

bmcpharmacoltoxicol.biomedcentral.com/articles/supplements/volume-20supplement-1.

\section{Authors' contributions}

CFAG wrote the first version of the manuscript. CFAG, SC, NRW, LMB, JWM $B C$, and SC contributed in the toxicological evaluation experiments and characterization of the impurities. MDA, SCG, CVG, NMV, EESS, and MS contributed in the experimental design of the study and revised the manuscript. All authors read and approved the manuscript.

\section{Funding}

This research was founded by CAPES and CNPq (Brazil).

\section{Availability of data and materials}

The data sets used and/or analyzed during the current study available from the corresponding author on reasonable request.

Ethics approval and consent to participate Not applicable.

\section{Consent for publication}

Not applicable. 


\section{Competing interests}

The authors declare that they have no competing interests.

\section{Author details}

'Laboratório de Controle de Qualidade Farmacêutico, Universidade Federal do Rio Grande do Sul (UFRGS), Porto Alegre, Brazil. " Laboratório de Toxicologia (LATOX), Universidade Federal do Rio Grande do Sul (UFRGS), Porto Alegre, Brazil.

\section{Published: 19 December 2019}

\section{References}

1. Segall MD, Barber C. Addressing toxicity risk when designing and selecting compounds in early drug discovery. Drug Discov Today. 2014;19:688-93.

2. Bernardi RM, D'avila FB, Todeschini V, Andrade JMM, Fröehlich P, bergold AM. Main degradation products of dabigatranetexilate evaluated by LC-UV and LC-ESI-MS, degradation kinetics and in vitro cytotoxicity studies. J Braz Chem Soc. 2015;26:660-6.

3. Codevilla CF, Lange ADC, Andrade JMM, Segalin J, Froehlich PE, Bergold AM. Photodegradation kinetics of lodenafil carbonate, structure elucidation of two major degradation products using UPLC-MS/MS and in vitro cytotoxicity. Anal Methods. 2013;5:6511-6.

4. Costa MCN, Barden AT, Andrade JMM, Oppe TP, Schapoval EES. Quantitative evaluation of besifloxacin ophthalmic suspension by HPLC, application to bioassay method and cytotoxicity studies. Talanta. 2014;119:367-74.

5. Emerce $E_{1}$ Cok I, Degim T. Determination of the impurities in drug products containing montelukast and in silico/in vitro genotoxicological assessments of sulfoxide impurity. Toxicol Lett. 2015;238:90-9.

6. Paim CS, Nogueira DR, Mitjans M, Lopez DR, Perez JL, Steppe M, Schapoval EES, Vinardell MP. Biological safety studies of gemifloxacin mesylate and related substances. Photochem Photobiol Sci. 2013:12:805-12.

7. Roy J. Pharmaceutical impurities - a mini review. AAPS PharmSciTech. 2002; 3:1-8

8. Nagpal S, Karan, Upadhyay A, Bhardwaj TR, Thakkar A. A review on need and importance of impurity profiling. Curr Pharm Anal. 2011;7:62-70.

9. Ahuja S. Assuring quality of drugs by monitoring impurities. Adv Drug Deliv Rev. 2007:59:3-11.

10. Jain D, Basniwal PK. Forced degradation and impurity profiling: recent trends in analytical perspectives. J Pharm Biomed Anal. 2013;86:11-35.

11. ICH - International Conference on Harmonisation of technical requirements for registration of pharmaceuticals for human use: Impurities in New Drug Substances Q3A(R2), 2006.

12. $\mathrm{ICH}$ - International Conference on Harmonisation of technical requirements for registration of pharmaceuticals for human use: Impurities in New Drug Products Q3B(R2), 2006.

13. Basaka AK, Raw AS, Al Hakim AH, Furness S, Samaan NI, Gill DS, Patel HB, Powers RF, Yu L. Pharmaceutical impurities: regulatory perspective for abbreviated new drug applications. Adv Drug Deliv Rev. 2007:59:64-72.

14. Robinson DI. Control of genotoxic impurities in active pharmaceutical ingredients: a review and perspective. Org Process Res Dev. 2010;14:946-59.

15. Raman NVSS, Prasad AVSS, Reddy KR. Strategies for the identification, control and determination of genotoxic impurities in drug substances: a pharmaceutical industry perspective. J Pharm Biomed Anal. 2011;55:662-7.

16. Dow KL, Hansen MM, Pack BW, Page TJ, Baertschi SW. The assessment of impurities for genotoxic potential and subsequent control in drug substance and drug product. J Pharm Sci. 2013;12:404-1417.

17. $\mathrm{ICH}$ - International Conference on Harmonisation of technical requirements for registration of pharmaceuticals for human use: Assessment and control of DNA reactive (mutagenic) impurities in pharmaceuticals to limit potential carcinogenic risk M7, 2014.

18. Giacco F, Brownlee M. Oxidative stress and diabetic complications. Circ Res. 2010;107(9):1058-70.

19. Ceriello PA. Oxidative stress and diabetes-associated complications. Endocr Pract. 2006;12:60-2.

20. Ribeiro G, Roehrs M, Bairros A, Moro A, Charão M, Araújo F, Valentini J, Arbo M, Brucker N, Moresco R, Leal M, Morsch V, Garcia SC. N-acetylcysteine on oxidative damage in diabetic rats. Drug Chem Toxicol. 2011;34(4):467-74.

21. Vicentini J, Valentini J, Grotto D, Paniz C, Roehrs M, Brucker N, Charão MF, Moro AM, Tonello R, Moreira AP, Buffon A, Beck M, Garcia SC. Association among microalbuminuria and oxidative stress biomarkers in patients with type 2 diabetes. J Investig Med. 2011;59(4):649-54.
22. Arbo MD, Silva R, Barbosa DJ, Silva DD, Rossato LG, Bastos ML, Carmo H. Piperazine designer drugs induce toxicity in cardiomyoblast h9c2 cells through mitochondrial impairment. Toxicol Lett. 2014;229:178-89.

23. OECD - Organization for Economic co-operation and development Guidance document on using cytotoxicity tests to estimate starting doses for acute oral systemic toxicity tests, vol. 129; 2010.

24. Silva DD, Silve $\mathrm{E}, \mathrm{Carmo} \mathrm{H}$. Combination effects of amphetamines under hyperthermia - the role played by oxidative stress. J Appl Toxicol. 2014;34 637-50.

25. Doktorovova S, Silva AM, Gaivão I, Souto EB, Teixeira JP, Martins-Lopes P. Comet assay reveals no genotoxicity risk of cationic solid lipid nanoparticles. J Appl Toxicol. 2014;34:395-403.

26. Vasquez MZ. Combining the in vivo comet and micronucleous assays: a practical approach to genotoxicity testing and data interpretation. Mutagenesis. 2010:25:187-99.

27. Chahal H, Chowdhury TA. Gliptins: a new class of oral hypoglycaemic agent. Q J Med. 2007:100:671-7.

28. Lobner D. Comparison of the LDH and MTT assays for quantifying cell death: validity for neuronal apoptosis? J Neurosci Methods. 2000;96:147-52.

29. Repetto G, Peso A, Zurita JL. Neutral red uptake assay for the estimation of cell viability/cytotoxicity. Nat Protoc. 2008;3:1125-31.

30. Fotakis $\mathrm{G}$, Timbrell JA. In vitro cytotoxicity assays: comparison of $\mathrm{LDH}$ neutral red, MTT and protein assay in hepatoma cell lines following exposure to cadmium chloride. Toxicol Lett. 2006:160:171-7.

31. Lebel CP, Ischiropoulos H, Bondy SC. Evaluation of the probe 2,7dichlorofluorescin as an indicator of reactive oxygen species formation and oxidative stress. Chem Res Toxicol. 1992;5:227-31.

32. Bryan NS, Grisham MB. Methods to detect nitric oxide and its metabolites in biological samples. Free Radic Biol Med. 2007;43:645-57.

33. Grisham MB, Jourd'Heuil D, Wink DA. Nitric oxide I. physiological chemistry of nitric oxide and its metabolites: implications in inflammation. Am J Physiol. 1999;276:G315-21.

34. Lee M, Kerns E. LC/MS applications in drug development. Mass Spectrom Rev. 1999;18:187-279.

35. Griffiths EJ. Mitochondria- potential role in cell life and death. Cardiovasc Res. 2000;46:24-7.

36. Ward MW, Huber HJ, Weisová P, Düssmann H, Nicholls DG, Prehn JHM. Mitochondrial and plasma membrane potential of cultured cerebellar neurons during glutamate-induced necrosis, apoptosis, and tolerance. J Neurosci. 2007;27:8238-49.

37. Kumaravel TS, Vilhar B, Faux SP, Jha A. Comet assay measurements: a perspective. Cell Biol Toxicol. 2009;25:53-64.

\section{Publisher's Note}

Springer Nature remains neutral with regard to jurisdictional claims in published maps and institutional affiliations.

Ready to submit your research? Choose BMC and benefit from:

- fast, convenient online submission

- thorough peer review by experienced researchers in your field

- rapid publication on acceptance

- support for research data, including large and complex data types

- gold Open Access which fosters wider collaboration and increased citations

- maximum visibility for your research: over $100 \mathrm{M}$ website views per year

At $\mathrm{BMC}$, research is always in progress.

Learn more biomedcentral.com/submissions 